\title{
Potential for water reuse in Vietnam
}

\author{
Tiềm năng tái sử dụng nước tại Việt Nam
}

\author{
OERTLÉ, Emmanuel ${ }^{1 *} ;$ VU, Duc Toan ${ }^{2} ;$ NGUYEN, Dinh Chuc ${ }^{3}$ N NÄF, Laurin ${ }^{1} ;$ MÜLLER, Sandra \\ Regina ${ }^{1}$
}

${ }^{1}$ Institute for Ecopreneurship, University of Applied Sciences and Arts Northwestern Switzerland (FHNW), Hofackerstrasse 30, CH-4132 Muttenz, Switzerland; ${ }^{2}$ Thuyloi University, 175 Tay Son Street, Hanoi, Vietnam; ${ }^{3}$ nstitute of Regional Sustainable Development, Vietnam Academy of Social Sciences, Vietnam Academy of Social Sciences, No.1 Lieu Giai, Hanoi, Vietnam.

\begin{abstract}
Southeast Asian countries and Vietnam in particular are facing water security challenges; water reclamation is increasingly being considered as a favorable solution. Despite the availability of suitable technologies, several constraints often prevent stakeholders and especially decision makers exploiting their potential. In this paper we present the results of applying a decision support tool (DST) to evaluate water reclamation, support pre-feasibility studies and build capacity for water reclamation in Vietnam. The DST and its data are open access, providing information related to local and international water and wastewater quality standards. In this research we identified high potential Vietnamese case studies and conducted a systematic PISTLE analysis considering six dimensions (Political, Institutional, Social, Technical, Legal and Economic) at a multi-local stakeholder workshop. Key barriers and drivers for the implementation of water reclamation were identified. Measures proposed during the workshop could serve as a starting point for the development of water reclamation projects in Vietnam.
\end{abstract}

Các nước Đông Nam Á và đặc biệt là Việt Nam nói riêng hiện đang phải đối mặt với những thách thức về đảm bảo an ninh nguồn nước; cải tạo nguồn nước hiện đang được xem là một giải pháp thuận lợi. Mặc dù các công nghệ phù hợp đã có sãn, nhưng một số hạn chế đã ngăn cản các bên liên quan và đặc biệt là những nhà làm chính sách có thể khai thác các tiềm năng của những công nghệ này. Trong bài báo này, chúng tôi trình bày các kết quả của việc áp dụng một công cu hỗ trợ quyết định (DST) để đánh giá việc cải tạo nguồn nước, hỗ trợ các nghiên cứu tiền khả thi và xây dựng các khả năng cải tạo nguồn nước ở Việt Nam. DST và dữ liệu của nó là nguồn truy cập mở, cung cấp thông tin liên quan đến những tiêu chuẩn về chất lượng nước và nước thải của địa phương và quốc tế. Trong nghiên cứu này, chúng tôi đã xác định các tình huống điển hình có tiềm năng cao của Việt Nam và tiến hành phân tích PISTLE có hệ thống xem xét sáu khía cạnh (Chính trị, Thể chế, Xã hội, Kỹ thuật, Pháp lý và Kinh tế) tại một hội thảo của các bên liên quan tại địa phương. Những rào cản chính và yếu tố vận hành của việc thực hiện cải tạo nguồn nước cũng đã được xác định. Các giải pháp được đề xuất trong hội thảo này có thể đóng vai trò là điểm khởi đầu để phát triển các dự án cải tạo nguồn nước ở Việt Nam.

Keywords: water reuse; wastewater recycling; water reclamation; decision support tool; water resources management; multi-criteria analysis; Vietnam

\section{Introduction}

Water or wastewater reclamation is the process of treating wastewater to turn it into water that can be used for beneficial purposes. Water reuse refers to the beneficial use of reclaimed water (the 'fit-for-purpose' concept (WWDAP (United Nations World Water Assessment Programme) 2017). The main incentive for water reclamation is this use of treated wastewater as a water resource for beneficial purposes as it can partly substitute the abstraction of fresh surface or groundwater. A second incentive is that wastewater is not discharged to receiving environments, thus reducing pollution of water bodies.
This research was carried out in relation to a United Nations Industrial Development Organisation (UNIDO) initiative and an educational workshop with 17 Vietnamese stakeholders in Switzerland on 10th May 2019. This workshop was part of a Swiss educational tour on eco-industrial parks, which aimed to clarify the potential for water reuse in Vietnam. The first objective of this workshop was to introduce the topic of water reclamation, since it is currently not used in Vietnam. The second was to demonstrate that water reclamation could have potential for selected case studies and to propose an initial ranking of technology options. The Vietnamese legal and regulatory context allows reuse of treated wastewater (Government of Vietnam 2012). As water reuse is not implemented in Vietnam yet, the third objective was to hold a stakeholder dialogue to identify barriers and drivers for implementation of water 
reuse and discuss necessary measures that could foster implementation.

In this paper we present the application of a decision support tool (DST) for evaluating the potential for water reclamation in Vietnam. The DST's objective is to identify technology options that can treat wastewater to the desired quality for several representative case studies, as defined in Table 1.

Table 1. Selected case studies (wastewater type, quantity and intended reuse)

\begin{tabular}{|c|c|c|c|}
\hline Case $\mathrm{N}^{\circ}$ & Wastewater type & Quantity $\left[\mathrm{m}^{3} / \mathrm{d}\right]$ & Intended reuse \\
\hline $1-A$ & Typical untreated municipal & \multirow{3}{*}{10,000} & \multirow{3}{*}{$\begin{array}{l}\text { Agricultural irrigation of non-food crops } \\
\text { (ISO Guidelines, cat. C) }\end{array}$} \\
\hline & wastewater (MWW) Vietnam & & \\
\hline $1-B$ & $\begin{array}{l}\text { Typical treated wastewater } \\
\text { (WW) Vietnam }\end{array}$ & & \\
\hline $2-A$ & Typical untreated MWW Vietnam & \multirow{2}{*}{10,000} & \multirow{2}{*}{$\begin{array}{l}\text { Restricted urban irrigation and agricultural irrigation of } \\
\text { processed food crops (ISO Guidelines, cat. B) }\end{array}$} \\
\hline $2-B$ & Typical treated WW Vietnam & & \\
\hline $3-A$ & Typical untreated MWW Vietnam & \multirow{2}{*}{10,000} & \multirow{2}{*}{$\begin{array}{l}\text { Unrestricted urban irrigation and agricultural irrigation of } \\
\text { food crops consumed raw (ISO Guidelines, cat. A) }\end{array}$} \\
\hline $3-B$ & Typical treated WW Vietnam & & \\
\hline $4-\mathrm{A}$ & $\begin{array}{l}\text { Typical eco-industrial park (EIP) Ef- } \\
\text { fluent - before treatment }\end{array}$ & \multirow{2}{*}{1,000} & \multirow{2}{*}{$\begin{array}{l}\text { Industrial Reuse - Recirculating Cooling Towers } \\
\text { (Texas EPA) }\end{array}$} \\
\hline $4-B$ & $\begin{array}{l}\text { Typical EIP Effluent - } \\
\text { after treatment }\end{array}$ & & \\
\hline
\end{tabular}

\section{The Vietnamese case studies}

\subsection{Water security and integrated water management in Vietnam}

Water pollution is one of the most critical environmental issues in Vietnam. The Ministry of Natural Resources and Environment states that almost $80 \%$ of diseases in Vietnam are caused by polluted water. Industrial zones discharge an estimated one million cubic metres of untreated wastewater per day directly to receiving water bodies (Ministry of Foreign Affairs Netherlands 2018). While urban wastewater is mainly treated in household septic tanks (55\%) and a small share is direct sewage (5\%). From these urban wastewater only a small share is actually treated (10\%).

While many urban wastewater projects have been accepted, most are not part of a comprehensive integrated water management concept and are implemented on a case-by-case basis. It seems that urban developers often delay construction of their wastewater treatment components in order to reduce capital and operation costs (World Bank 2013).

Provincial or city budgets cover most of the costs related to operation and maintenance of drainage and wastewater treatment systems, but this budget only meets about 10 $20 \%$ of costs for collection systems. Income from wastewater operations is mostly generated through a wastewater surcharge on customers' water bills (Ministry of Foreign Affairs Netherlands 2018).

Without much investment, 30\% of water in the textile, food processing and leather sectors could be saved. Investment opportunities may exist through donor-funded development of 'eco-industrial parks' to make existing industrial zones more sustainable, for example with the provision of wastewater treatment techniques and nutrient recovery. To this end, UNIDO has initiated projects in the catchment areas of the two largest rivers in Vietnam, the Mekong River and Red River (Ministry of Foreign Affairs Netherlands 2018).

Since 1995, Vietnam has constantly adapted regulations and standards to meet wastewater challenges. While it has improved the legal framework and set the basis for ecoindustrial parks, those changes also created uncertainty among local governments when designing and implementing wastewater projects (Ministry of Foreign Affairs Netherlands 2018).

Vietnam has a comprehensive legal framework in environmental sanitation, including urban wastewater management, albeit with some shortcomings. There are overly ambitious and sometimes conflicting targets for environmental protection and wastewater collection and treatment and there is a lack of synchronization as well as overlaps and gaps in various Ministries' regulations. Moreover few incentives are provided to encourage private sector investment in the wastewater business (World Bank 2013).

Deficiencies outside the legal frameworks include limited staff and funding for environmental monitoring, insufficient enforcement because of corruption and inadequate resources, as well as low penalties for non-compliance and little public disclosure of industrial pollution information (Ministry of Foreign Affairs Netherlands 2018).

\subsection{Typical wastewater quality in Vietnam, regulations and selected case studies}


There are no official regulations for wastewater use in Vietnam, except for maximum total coliform (TC) for effluent discharge to surface water (US-EPA 2012). Currently applied regulations are for effluent standards and have undergone significant change since the first standard was issued in 1995. Current effluent standards in Vietnam specify water quality parameters as Class A or Class B depending on whether treated wastewater is discharged to water bodies with a function of drinking water supply (Class A) or not (Class B) (World Bank 2013). For water use in agriculture, the national technical regulation on water quality for irrigation (QCVN 39: 2011/BTNMT) applies (Phuong and Nguyen 2013).

Typical wastewater qualities from municipal wastewater for 12 water quality parameters are shown in Table 9 (Appendix I - Water quality parameters for the Vietnamese case study). Most effluent qualities (after treatment) meet water quality standard class A (discharge with drinking water function) and all effluent qualities meet the parameters of class B (discharge without drinking water function). Regarding irrigation water quality, only two parameters from the regulations correspond to the selected set of twelve parameters: Faecal Coliform (FC) and total dissolved solids (TDS). However, no information was found on those parameters from typical wastewater.

The following example assessment uses national and international water quality guidelines and typical wastewater quality profile types that have been established based on Vietnamese data and complemented with typical international qualities for unknown parameters (World Bank 2013, Asano et al. 2007). If available, water quality parameter values from Hanoi have been considered (named Kim Lien), otherwise values based on typical international case studies have been considered (Table 9 in APPENDIX I - Water quality parameters for the Vietnamese case study). Based on our data research, eight case studies for water reuse in Vietnam have been established (Table 1) with corresponding water qualities considered (Table 2).

Table 2. Selected wastewater and water quality requirements

\begin{tabular}{|c|c|c|c|c|c|c|c|c|c|c|c|}
\hline $\begin{array}{l}\text { Water } \\
\text { quality } \\
\text { classes }\end{array}$ & $\begin{array}{l}\text { Turb } \\
\text { NTU }\end{array}$ & $\begin{array}{c}\text { TSS } \\
\mathrm{mg} / \mathrm{L}\end{array}$ & $\begin{array}{l}\text { BOD } \\
\mathrm{mg} / \mathrm{L}\end{array}$ & $\begin{array}{l}\text { COD } \\
\mathrm{mg} / \mathrm{L}\end{array}$ & $\begin{array}{r}\mathrm{TN} \\
\mathrm{mg} / \mathrm{L}\end{array}$ & $\begin{array}{r}\text { TP } \\
\mathrm{mg} / \mathrm{L}\end{array}$ & $\begin{array}{r}\mathrm{FC} \\
\mathrm{CFU} / \\
100 \mathrm{ml}\end{array}$ & $\begin{array}{r}\mathrm{TC} \\
\mathrm{CFU} / \\
100 \mathrm{ml}\end{array}$ & $\begin{array}{l}\text { TDS } \\
\mathrm{mg} / \mathrm{L}\end{array}$ & $\begin{array}{l}\text { Nitrate } \\
\mathrm{mg} \mathrm{N} / \mathrm{L}\end{array}$ & $\begin{array}{l}\text { TOC } \\
\mathrm{mg} / \mathrm{L}\end{array}$ \\
\hline \multicolumn{12}{|l|}{ ISO-Guidelines } \\
\hline $\begin{array}{l}\text { Cat A irrigation of } \\
\text { food crops con- } \\
\text { sumed raw }\end{array}$ & 5 & 10 & 10 & - & - & - & - & 100 & - & - & - \\
\hline $\begin{array}{l}\text { Cat. B: irrigation of } \\
\text { processed food } \\
\text { crops }\end{array}$ & - & 25 & 20 & - & - & - & - & 1,000 & - & - & - \\
\hline $\begin{array}{l}\text { Cat. C: irrigation of } \\
\text { non-food crops }\end{array}$ & - & 50 & 35 & - & - & - & - & 10,000 & - & - & - \\
\hline
\end{tabular}

\section{Texas water re-use standards}

\begin{tabular}{|c|c|c|c|c|c|c|c|c|c|c|c|}
\hline $\begin{array}{l}\text { Texas EPA: Industrial- } \\
\text { Reuse- Recirculating } \\
\text { Cooling Towers }\end{array}$ & & - & 20.00 & - & - & - & 200.00 & - & - & - & - \\
\hline \multicolumn{12}{|c|}{ Typical municipal wastewater Vietnam } \\
\hline $\begin{array}{l}\text { Typical untreated } \\
\text { MWW Vietnam }\end{array}$ & 100 & 86 & 94 & 189 & 44 & - & 10,000 & $1 E+07$ & 720 & 18 & 140 \\
\hline $\begin{array}{l}\text { Typical treated WW } \\
\text { Vietnam }\end{array}$ & 2 & 6 & 11 & 22 & 16 & - & - & 10,000 & 500 & 3 & 10 \\
\hline
\end{tabular}

Vietnam

\begin{tabular}{|c|c|c|c|c|c|c|c|c|c|c|c|}
\hline $\begin{array}{l}\text { Typical IP Effluent - } \\
\text { before treatment }\end{array}$ & - & 200 & 200 & 400 & 60 & 8 & - & 3,000 & - & - & - \\
\hline $\begin{array}{l}\text { Typical IP Effluent - } \\
\text { after treatment }\end{array}$ & - & 49.5 & 29.7 & 49.5 & 14.85 & 3.96 & - & 3,000 & - & - & - \\
\hline
\end{tabular}

\section{Typical river Vietnam}

\begin{tabular}{l}
$\begin{array}{l}\text { Typical River } \\
\text { Vietnam }\end{array}$ \\
\hline
\end{tabular}




\section{Materials and methods}

\subsection{Decision support tool for water reuse (Poseidon)}

To assess the defined case studies, an existing DST named Poseidon was used (Oertlé et al. 2019) and complemented with additional Vietnamese and international data. Wastewater quality data, different regulations and key data for national cost calculation were included in the DST (Table 3). Poseidon DST is available as open access at the Zenodo repository: http://doi.org/10.5281/zenodo. 1971933 (Oertlé 2018).

The DST was applied to every case study defined (Figure 1). The first ranking options for treatment trains that show the lowest lifecycle treatment cost (USD per cubic metre) were ranked based on the following weighting of evaluation criteria (Figure 2).

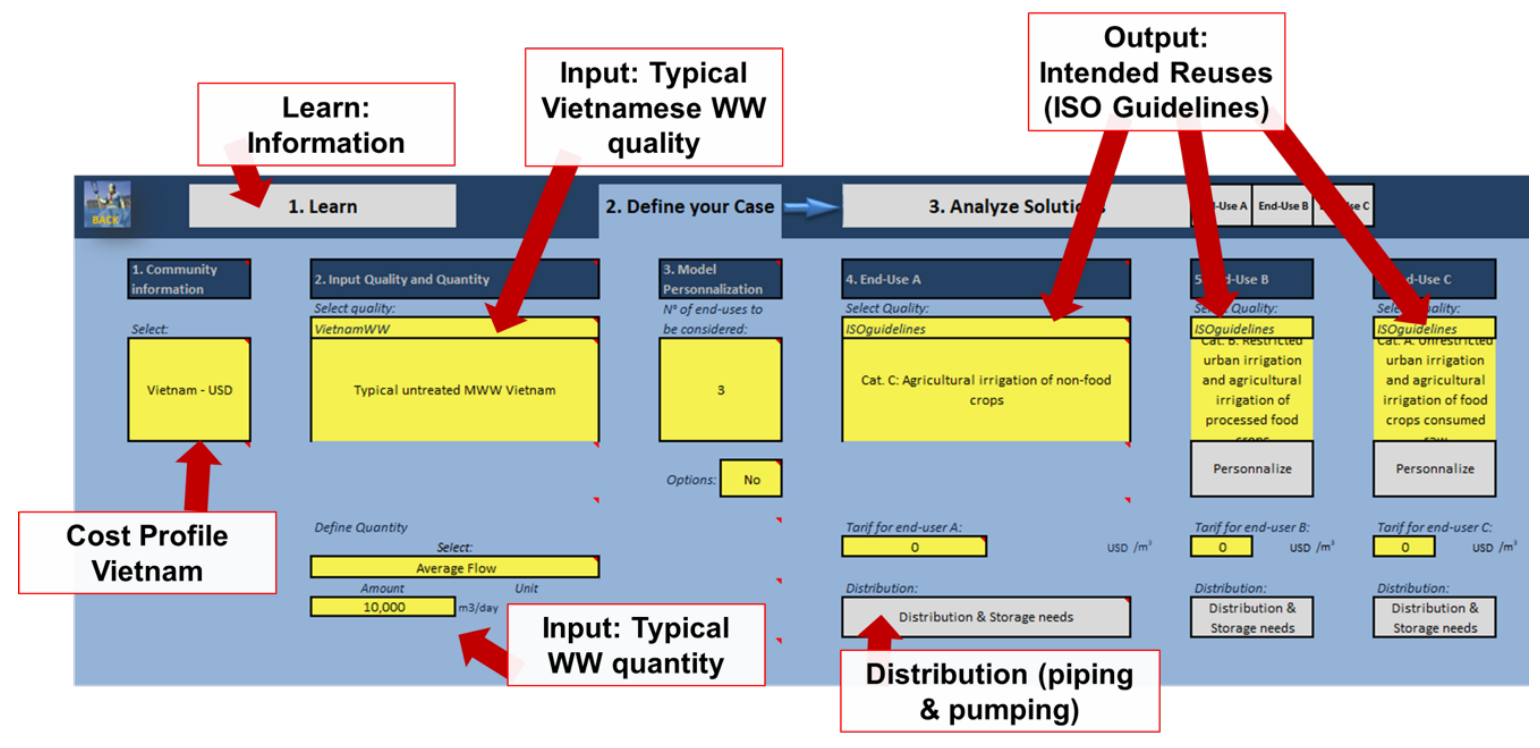

Figure 1. Application of Poseidon

Table 3. Parameters considered in the Vietnamese community profiles for the calculation of the cost component

\begin{tabular}{|c|c|c|c|c|}
\hline Parameters & Unit & Default value & Reference & Comment \\
\hline Currency & [VND] & Vietnamese Dong & & $\begin{array}{l}\text { The reference community is based on USD from } \\
2006 \text {. }\end{array}$ \\
\hline \multirow[t]{2}{*}{$\begin{array}{l}\text { Exchange rate } \\
\text { to USD } 2006\end{array}$} & [VND / USD] & $16,191(2006)$ & $\begin{array}{l}\text { (European } \\
\text { Commission 2019) }\end{array}$ & $\begin{array}{l}\text { To define the exchange rate, use that from } 2006 \\
\text { and include inflation and other evolution factors } \\
\text { since 2006. (European Commission) }\end{array}$ \\
\hline & & 20,418 & $\begin{array}{l}\text { (Coinnews Media } \\
\text { Group LLC 2018) }\end{array}$ & \\
\hline Land cost & {$\left[\mathrm{VND} / \mathrm{m}^{2}\right]$} & $2,500,000$ & (World Bank 2015) & $\begin{array}{l}\text { Acquisition costs and unit costs for land have to } \\
\text { be merged into this overall land cost factor. } \\
\text { Cheapest land on smaller roads and alleyways. }\end{array}$ \\
\hline $\begin{array}{l}\text { Electricity cost } \\
2018\end{array}$ & {$[U S D / k W h]$} & 0.07 & $\begin{array}{l}\text { (GlobalPetrolPrices.com } \\
\text { 2018) }\end{array}$ & Average electricity cost should be used. \\
\hline Personal cost & [VND/per month] & $37,500,000$ & $\begin{array}{l}\text { (Arcadis Vietnam Co. } \\
\text { Ltd 2017) }\end{array}$ & $\begin{array}{l}\text { Minimum wage for enterprises operating in re- } \\
\text { gion I (most expensive) }\end{array}$ \\
\hline $\begin{array}{l}\text { Discount rate } \\
\text { (r) } 7.10 .2017\end{array}$ & $\% / a$ & $4.25 \% / a$ & $\begin{array}{l}\text { (Central Intelligence } \\
\text { Agency 2019) }\end{array}$ & $\begin{array}{l}\text { Real interest rate } r=\text { nominal interest rate }(i) \text { - } \\
\text { actual inflation rate }(p)\end{array}$ \\
\hline
\end{tabular}




\begin{tabular}{|c|c|}
\hline \multicolumn{2}{|c|}{ Technical evaluation } \\
\hline Reliability & Important \\
\hline Ease to upgrade & $\begin{array}{l}\text { Not important (not } \\
\text { considered) }\end{array}$ \\
\hline $\begin{array}{l}\text { Adaptability to varying } \\
\text { flow }\end{array}$ & $\begin{array}{l}\text { Not important (not } \\
\text { considered) }\end{array}$ \\
\hline $\begin{array}{l}\text { Adaptability to varying } \\
\text { quality }\end{array}$ & Important \\
\hline Ease of $O \& M$ & Very Important \\
\hline Ease of construction & $\begin{array}{l}\text { Not important (not } \\
\text { considered) }\end{array}$ \\
\hline Ease of demonstration & $\begin{array}{l}\text { Not important (not } \\
\text { considered) }\end{array}$ \\
\hline
\end{tabular}

\begin{tabular}{|c|c|}
\hline \multicolumn{2}{|c|}{ Requirements and impacts } \\
\hline Power demand & Regular \\
\hline Chemical demand & $\begin{array}{l}\text { Not important (not } \\
\text { considered) }\end{array}$ \\
\hline Odor generation & $\begin{array}{l}\text { Not important (not } \\
\text { considered) }\end{array}$ \\
\hline $\begin{array}{l}\text { Impact on ground } \\
\text { water }\end{array}$ & $\begin{array}{l}\text { Not important (not } \\
\text { considered) }\end{array}$ \\
\hline Land requirment & $\begin{array}{l}\text { Not important (not } \\
\text { considered) }\end{array}$ \\
\hline Cost of treatment & Important \\
\hline $\begin{array}{l}\text { Quantity of sludge } \\
\text { production }\end{array}$ & $\begin{array}{l}\text { Not important (not } \\
\text { considered) }\end{array}$ \\
\hline
\end{tabular}

Figure 2. Weighting profile applied with assessment criteria for multi criteria analysis with qualitative or semi-quantitative information.

\subsection{Workshop and Vietnamese delegation}

The stakeholders at the workshop were representatives from the Government of Vietnam and key experts from different ministries (Ministry of Planning and Investment, Ministry of Construction, Ministry of Finance, Ministry of Science and Technology and Ministry of Natural Resources and Environment). Furthermore, the workshop was attended by park managers (Ninh Binh, Da Nang Hightech Park and Can Tho Processing Industrial Zones) and relevant stakeholders engaged in industrial park management and industrial production (representatives from Project Implementation of the Eco- industrial park initiative for sustainable industrial zones and from Vietnam Academy of Social Sciences). During the workshop, the stakeholders were trained in order to strengthen the Vietnamese national capacity for implementation of Decree 82 and in particular its Eco-industrial Park (EIP) elements. The objective was to support the key Vietnamese ministries and authorities in drafting and endorsing the ministerial circulars on EIP development. Wastewater management is a crucial aspect of industrial park management and as stakeholders are involved at different influential levels in Vietnam, it was decided to include the topic of water reclamation in the workshop.

In preparing the workshop in Switzerland, efforts were made to gather relevant data that have been integrated in the current research. The stakeholders applied the DST for the selected case studies and after the presentation of the results, a guided stakeholder dialogue was conducted to answer the following questions:

1. How do you perceive the potential for water reuse in Vietnam? What type of reuse has most potential?

2. What are the main barriers and drivers for water reuse in Vietnam?

3. What measures would be necessary to overcome the barriers identified?

The workshop was moderate. This and this paper includes the main outcomes.

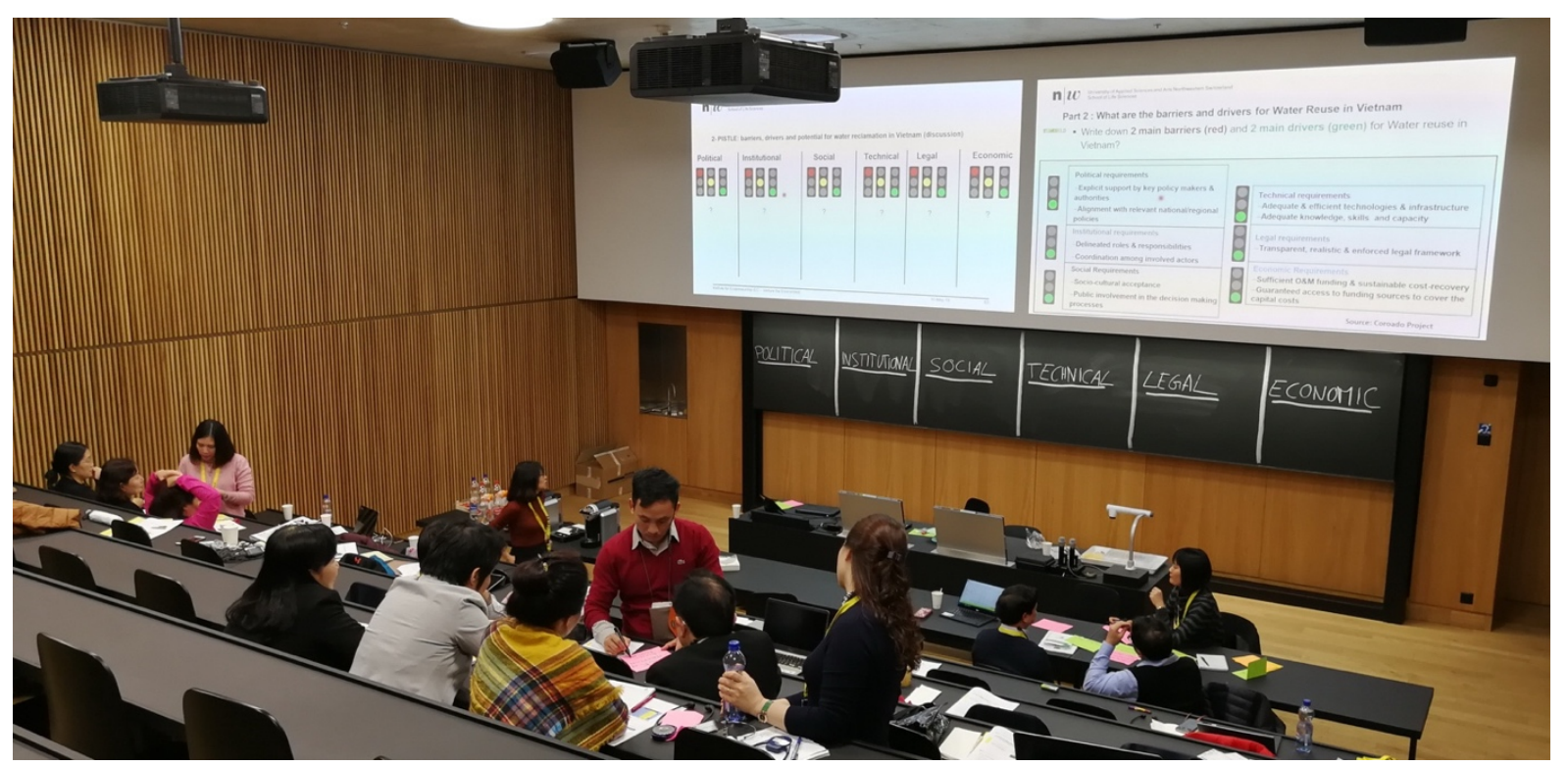

Figure 3. Workshop stakeholders during the dialogue identifying barriers and drivers for water reuse. 


\section{Results}

\subsection{Decision support tool}

For every case study considered, treatment trains ( $\Pi$, which are a series of unit process technologies) complying with the water quality requirements were identified (Table 4). Figure 4 presents the detailed results for case study $1 \mathrm{~A}$. The results include the two first ranking options based on cost and then the first ranking option based on weighted evaluation factors for all case studies considered. Those results are a good indication of the potential for water reuse and potential treatment trains. However this is a simplified pre-feasibility assessment with limitations, as it is only based on the twelve parameters defined in the DST. Additional parameters currently not considered should be included in future feasibility studies. Industrial wastewater in particular might contain specific contamination such as heavy metals, dyes, bleach or other chemicals.

Nevertheless, the results showed that there is potential for water reuse in Vietnam and there are available technologies that could treat typical Vietnamese wastewater to comply with international standards. For cases 1-3, many identified options have a cost ranging between 0.22-0.54 USD per cubic meter for reclaimed water and thus comply with international standards (0.37-1 USD per cubic meter for case 4 at a smaller scale).

Table 4. Two first ranking options based on cost and first ranking option based on weighted evaluation factors for all case studies considered.

\begin{tabular}{|c|c|c|c|c|c|c|}
\hline Case $\mathrm{N}^{\circ}$ & $\pi 1$ (cost) & Cost [USD/m $\left.\mathrm{m}^{3}\right]$ & $\Pi 2$ (cost) & Cost [USD/m $\left.\mathrm{m}^{3}\right]$ & TT3 (weights) & Cost [USD $\left./ \mathrm{m}^{3}\right]$ \\
\hline $1-A$ & Lagooning: Australia I & 0.22 & Title 22: Spain & 0.25 & Wetlands: Spain & 0.54 \\
\hline $1-B$ & No treatment & 0.00 & 0 & 0.00 & No treatment & 0.00 \\
\hline $2-A$ & Lagooning: Australia I & 0.22 & Title 22: Spain & 0.25 & Only disinfection: Chile & 0.51 \\
\hline $2-B$ & Lagooning: Australia I & 0.22 & Lagooning: Australia II & 0.25 & Wetlands: Spain & 0.54 \\
\hline $3-A$ & Lagooning: Australia I & 0.22 & Title 22: Belgium & 0.52 & Lagooning: Australia I & 0.22 \\
\hline $3-B$ & Lagooning: Australia I & 0.22 & Lagooning: Australia II & 0.25 & Wetlands: Spain & 0.54 \\
\hline $4-\mathrm{A}$ & Lagooning: Australia I & 0.58 & Lagooning: Argentina & 0.64 & Wetlands: Spain & 1.01 \\
\hline $4-B$ & Wetlands: Nicaragua & 0.37 & Wetlands: Brazil & 0.38 & Wetlands: Spain & 1.01 \\
\hline
\end{tabular}

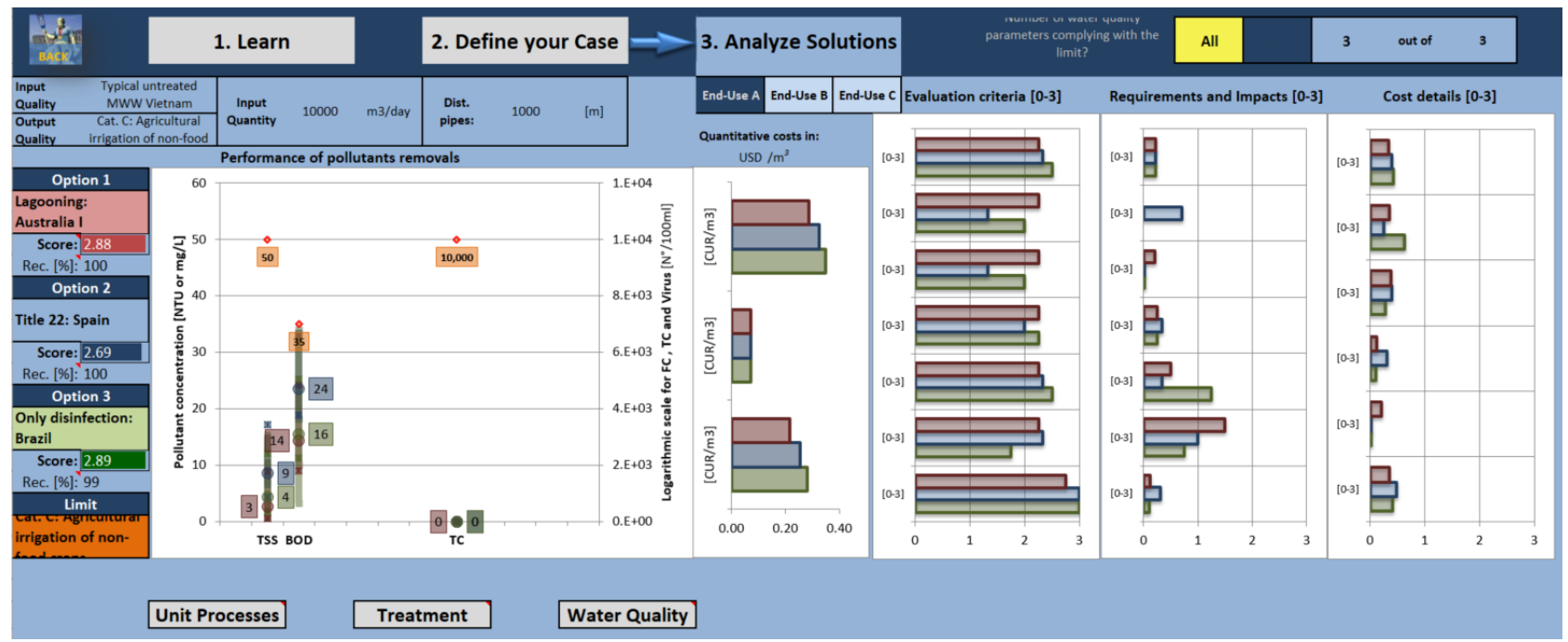

Figure 4. Case 1A: Typical untreated MWW for agricultural irrigation of non-food crops (ISO Guidelines, cat. C): three first ranking options based on cost

\subsection{First ranking options identified}

Table 4 presents the identified treatment trains based on the list of 70 treatment trains included in the DST. These are mostly based on typical benchmark technologies and on case studies from around the world. Results show that three treatment trains highly ranked in the assessment have a high potential for the defined case studies namely: Lagooning Australia I, Title 22: Spain and Wetlands Spain. The identified treatment train reference case studies have the following characteristics; the cost factors are listed in Table 5 .

Lagooning Australia: WWTP effluents are re-used for horticultural irrigation. Main irrigated crops are root and salad crops, brassicas, grapes and olives (=unrestricted irrigation). Sewage is treated in the WWTP by activated sludge process. The effluents from secondary treatment are then held in shallow aeration lagoons for a minimum of 6 weeks, before passing through a dissolved air flotation and dual media filtration process at the water reclamation plant. 
Here, the effluents discharge to balancing storage via a chlorinator before being pumped into the pipeline for horticultural irrigation distribution (AQUAREC, 2006).

Title 22 - Spain: The secondary effluent from a WWTP in Madrid is reclaimed in a tertiary treatment that includes sand filtration and disinfection. After UV disinfection, the reclaimed water is sent to the main reservoirs and then delivered for park irrigation. The main reservoirs are chlorinated (Chlorine dioxide is used as the secondary disinfectant) (AQUAREC, 2006). Only the tertiary treatment step is displayed here.

Wetlands Spain: The WWTP is of the extended aeration type and consists, in its current form, of a mechanical pretreatment step and then two parallel treatment lines, each comprising a biological reactor, a clarifier and three effluent polishing ponds. There is also a chemical treatment for phosphorus removal. Further treatment is achieved by means of a wetland system (3 parallel cells) (AQUAREC, 2006; Sala et al., 2004).

Table 5. Cost factors for three typical treatment trains that comply with several case studies.

\begin{tabular}{llrrr} 
Cost factors & Unit & Lagooning Australia I & Title 22: Spain & Wetlands Spain \\
\hline Capital Costs per year & {$[1,000$ USD/year $]$} & 462 & 462 & 768 \\
Capital Expenditure (CAPEX) & {$[1,000$ USD] } & 7,750 & 7,750 & 12,882 \\
Land Cost per year & {$[1,000$ USD/year $]$} & 21 & 21 & 110 \\
Energy cost per year & {$[1,000$ USD/year $]$} & 36 & 36 & 93 \\
Labour cost per year & {$[1,000$ USD/year $]$} & 42 & 42 & 113 \\
Other Operation and Maintenance costs per year & {$[1,000$ USD/year $]$} & 227 & 227 & 879 \\
Total costs per year & {$[1,000$ USD/year $]$} & 787 & 787 & 1,962 \\
End Flow per year & {$\left[1,000 \mathrm{~m}^{3} /\right.$ year $]$} & 3,650 & 3,650 & 3,613 \\
Cost / m & {$\left[\right.$ USD $\left./ \mathrm{m}^{3}\right]$} & 0.22 & 0.22 & 0.54
\end{tabular}

\subsection{Stakeholder workshop}

The stakeholders were divided into three mixed groups working in parallel to answer the three main questions of the participatory workshop. The first question addressed the perceived potential for water reuse in Vietnam and the type of reuse that showed the most potential. All

\section{Table 6. Study Groups' perception of wastewater reuse potential and type of reuse}

\begin{tabular}{lll} 
Group & Potential & Type of reuse \\
\hline 1 & High & Agriculture irrigation, Landscape irrigation, Industrial Reuse \\
2 & High & Industrial Reuse \\
3 & Average & Industrial Reuse, Agriculture irrigation, Ecological
\end{tabular}

The second question from the stakeholder dialogue, resulted to similar number of barriers and drivers (Table 7). Regarding political and social dimensions no significant barriers were identified and the stakeholders evaluated those two categories as being favourable to the implementation of water reclamation (green). Regarding the institutional, technical and economic dimensions, both barriers and drivers were identified, but no clear trend could be established. This led to a neutral evaluation of those stakeholders specified a potential ranging between average and high for wastewater reuse in Vietnam (two groups out of three perceived a high potential) (Table 6). While all stakeholders saw opportunities in the industrial sector, two groups mentioned that water could potentially be reused for agriculture. Reuse of water for landscape irrigation or ecological reasons was also mentioned by one group.

categories (yellow). The legal dimension showed important barriers, especially due to the lack of regulations; the stakeholders estimated that this category is a significant barrier to the implementation of water reuse in Vietnam (red). In the stakeholder evaluation, the workshop was assessed as 'very good' to 'excellent'. In particular, the dialogue was perceived as excellent and additional future workshops were requested. 
Table 7. The defined barriers and drivers and their evaluation in the PISTLE framework.

\begin{tabular}{|c|c|c|c|c|c|c|}
\hline & Political & Institutional & Social & Technical & Legal & Economic \\
\hline Drivers & Clear direction & $\begin{array}{l}\text { In process of im- } \\
\text { provement }\end{array}$ & $\begin{array}{l}\text { 1) High demand } \\
\text { for using } \\
\text { recycled water } \\
\text { 2) Social } \\
\text { requirements }\end{array}$ & $\begin{array}{l}\text { 1) Best Available } \\
\text { Technology (BAT) } \\
\text { 2) Several good } \\
\text { practices available }\end{array}$ & $\begin{array}{l}\text { 1) Green Growth } \\
\text { Strategy } \\
\text { 2) Decree } 82\end{array}$ & $\begin{array}{l}\text { 1) Economic } \\
\text { requirements } \\
\text { 2) Economic benefits } \\
\text { 3) Protection of } \\
\text { environment and } \\
\text { public health } \\
\text { 4) Private investment } \\
\text { possible }\end{array}$ \\
\hline
\end{tabular}

\begin{tabular}{|c|c|c|c|c|c|c|}
\hline Barriers & $\begin{array}{l}\text { Lack of political } \\
\text { regulations }\end{array}$ & $\begin{array}{l}\text { 1) Overlap and gaps } \\
\text { in responsibility of } \\
\text { stakeholders } \\
\text { 2) Institutional re- } \\
\text { quirement (Coordi- } \\
\text { nation among } \\
\text { actors) }\end{array}$ & $\begin{array}{l}\text { No/Little } \\
\text { confidence in } \\
\text { quality }\end{array}$ & $\begin{array}{l}\text { 1) Inadequate skills } \\
\text { and knowledge } \\
\text { 2) Old technology } \\
\text { may not fit modern } \\
\text { technology }\end{array}$ & $\begin{array}{l}\text { 1) Legal requirements } \\
\text { 2) Lack of instructions } \\
\text { and standards for } \\
\text { water reuse } \\
\text { 3) Lack of perception } \\
\text { and policy regulations }\end{array}$ & $\begin{array}{l}\text { 1) Small-medium en- } \\
\text { terprises are } \\
\text { financially weak } \\
\text { 2) Preferential credit } \\
\text { available, but with } \\
\text { strict and compli- } \\
\text { cated procedures }\end{array}$ \\
\hline
\end{tabular}

\begin{tabular}{lllll|l|l}
\hline Evaluation & + & 0 & 0 & - & 0 \\
\hline
\end{tabular}

The third question aimed to propose measures to overcome the barriers identified. Based on the answers to the previous questions, stakeholders selected the legal and economic dimensions for which to propose measures.

Regarding the economic dimension, all groups agreed that more financial incentives for economic actors are needed. These should support actors that intend to be involved in wastewater reuse. As for the legal dimension, the stakeholders agreed that the plethora of existing documents would need to be unified to establish clear and unique guidance for all the ministries. One group mentioned that the regulations would also need to be extended in relation to water reuse. Even though decree 82, which allowed the reuse of treated wastewater in industrial parks, was implemented in 2018, there is a lack of other regulations and standards such as wastewater reuse in agriculture. The introduction of a bonus-malus system was another idea that could drive development in this sector.

Table 8. The stakeholders proposed measures to improve wastewater reuse in Vietnam

\begin{tabular}{lll} 
Group & Economic Measures & Legal Measures \\
\hline 1 & 1) Private, Public and Third Party (PPP) & 1) Develop a complete standard for wastewater reuse \\
2) Apply payback rewards to successful implementations & 2) Environmental technology must be prioritized legally \\
\hline 2 & 1) Financial incentives for investors & 1) Completion of the existing legal framework \\
2) Tariff incentives for treated wastewater users & 2) Sanctions for not using recycled/treated water \\
\hline 1) Incentives from government & 2) BAT Database & 1) Update regulations on reuse of wastewater \\
\end{tabular}

\section{Conclusions}

This study demonstrates the application of a decision support tool for water reuse to the Vietnamese case study. Preliminary research identified key data on typical wastewater quality in Vietnam and current water quality regulations for water reuse. Some gaps were identified and missing parameters were complemented with values from international case studies to identify four typical cases showing potential for water reuse implementation in $\mathrm{Vi}$ etnam.

For all defined case studies, adapted treatment trains that could treat wastewater to the desired quality at reasonable costs were identified and are presented in this paper. The results show that technological options are available for water reuse in Vietnam but the concept is not yet implemented there.
The participatory workshop organized with 17 local stakeholders and key experts indicated that there is a high potential for water reuse in Vietnam and that the political context and social acceptance is favourable to the implementation of water reuse. The main barriers hampering implementation of water reuse were legal and economic dimensions according to the stakeholders.

Several measures were identified in those categories with the aim of fostering implementation of water reuse and enabling a favourable environment. It seems that the most important measures to be adopted focus on simplification and unification of water quality regulations, since those are currently complicated and not coordinated among ministries. Furthermore, financial incentives and diverse economic instruments were also suggested by the 
stakeholders, even though many funds are available from donor agencies to support such projects in Vietnam.

The material developed for and used during the workshop are free of charge to the Vietnamese stakeholders. The future will show whether this initiative will support change and the implementation of water reclamation in Vietnam.

Future research into water reuse in Vietnam should (i) focus on specific case studies with high potential for water reuse and (ii) identify exemplary cases to implement demonstration sites for wastewater reclamation at an affordable cost.

\section{References}

[1] Arcadis Vietnam Co. Ltd. (2017). Construction Cost Handbook. Retrieved from https://images.arcadis. com/media/2/C/9/\%7B2C931A7A-A8B0-4D31-AF3433313DE7FODD\%7DConstruction Cost Handbook 2017Vi-

etnam.pdf?_ga=2.164429750.863789622.15479854 96-1731018836.154798549

[2] Asano, T., Burton, F., \& Leverenz, H. (2007). Water reuse: issues, technologies, and applications (Metcalf \& Eddy, Ed.). McGraw-Hill.

[3] Central Intelligence Agency. (2019). The World Factbook. Retrieved April 23, 2019, from https://www.cia.gov/library/publications/the-worldfactbook/geos/vm.html\#field-anchor-economy-economy-overview

[4] Coinnews Media Group LLC. (2018). Inflation Calculator. Retrieved April 30, 2019, from https://www.usinflationcalculator.com/

[5] European Commission. (n.d.). InforEuro - Monthly accounting rate of the euro.

[6] European Commission. (2019). Exchange rate. Retrieved April 30, 2019, from http://ec.europa.eu/budget/graphs/inforeuro.html

[7] Government of Vietnam. (2012). Law on Water Resources. Retrieved from http://www.wepa-db.net/policies/law/vietnam/lwr.htm

[8] Ministry of Foreign Affairs Netherlands. (2018). Scoping Study Circular Economy in Vietnam.

[9] Oertlé, E. (2018). Poseidon - Decision Support Tool for Water Reuse (Microsoft Excel) and Handbook. https://doi.org/10.5281/zenodo.1971933

[10] Oertlé, E., Hugi, C., Wintgens, T., Karavitis, C., Oertlé, E., Hugi, C., ... Karavitis, C. A. (2019). Poseidon-Decision Support Tool for Water Reuse. Water, 11(1), 153. https://doi.org/10.3390/w11010153

[11] Phuong, T., \& Nguyen, L. (2013). The Legal Framework of Vietnam's Water Sector: Update 2013. Retrieved from http://mpra.ub.uni-muenchen.de/52996/

[12] US-EPA. (2012). Guidelines for Water Reuse 2012. Washington DC, USA: EPA [United States Environmental Protection Agency].

[13] World Bank. (2013). Vietnam Urban Wastewater Review. 1-158.

[14] World Bank. (2015). Vietnam Affordable Housing: A Way Forward. The World Bank, 23(4), 39-46. https://doi.org/10.1353/jod.2012.0070

[15] WWDAP (United Nations World Water Assessment Programme). (2017). WWDR6 - The United Nations World Water Development Report 2017. Wastewater: the Untapped Resource. https://doi.org/10.1016/ j.aqpro.2013.07.003 